\title{
CORRELATION BETWEEN AGE, WEIGHT AND BODY MEASURES AT FIRST PREGNANCY OF NELLORE HEIFERS
}

\author{
(Correlação entre idade, peso e morfometria corporal com o estabelecimento de \\ prenhez em novilhas Nelore)
} \author{
Sereno $^{3}$

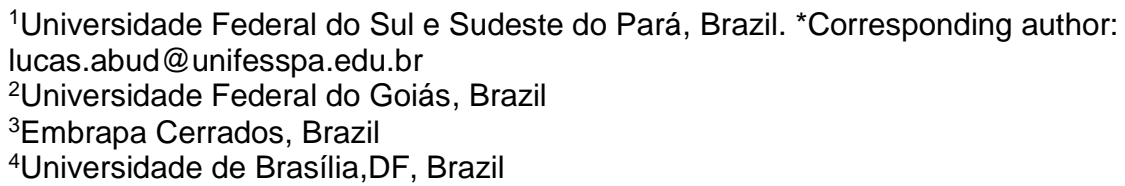

Lucas Jacomini Abud ${ }^{1 *}$, Cátia Oliveira Guimarães Abud ${ }^{1}$, Gustavo Lage Costa², Maria Clorinda Soares Fioravanti $^{2}$, Carlos Frederico Martins ${ }^{3}$, Concepta Margaret McManus Pimentel ${ }^{4}$, José Robson Bezerra

ABSTRACT: The objective of this study was to characterize and correlate weight, body condition and morphometric measurements with the beginning of the reproductive life in heifers of the Nellore breed. To determine the age of first pregnancy, 56 heifers of the Nellore breed were exposed to bulls. The females were evaluated for weight, body condition and body measurements every two months, from 16 to 32 months of age. The body measurements were: withers height, rump height, body length, head length, rump length, ear length, distance between ribs, distance from dorsal spine to belly, distance from ground to belly, head width, rump width, distance between ischiums, ear width, cannon bone perimeter, tail implantation perimeter, and thoracic perimeter. The results show that the animals had an average weight of $334 \pm 39 \mathrm{~kg}$ and an average age of $29 \pm 3$ months at first pregnancy. The morphometric measurements of withers height, rump height, body length, rump length, head width, rump width, width between ischiums, tail implantation perimeter and thoracic perimeter were significantly greater in the pregnant animals. Can conclude from these results that a relationship between morphometric measurements and the first pregnancy in Nellore heifers.

Keywords: beef cattle; morphometric measurements; sexual precocity

RESUMO: Objetivou-se, com este estudo, caracterizar e correlacionar o peso, condição corporal e medidas morfométricas corporais como início da vida reprodutiva em novilhas Nelore. Para a determinação da idade a primeira prenhez foram utilizadas 56 novilhas da raça Nelore expostas a touros. As fêmeas foram avaliadas quanto ao peso, condição corporal e morfometria corporal a cada dois meses, dos 16 aos 32 meses de idade. As medidas corporais foram: altura da cernelha, altura do posterior, comprimento do corpo, comprimento da cabeça, comprimento da garupa, comprimento da orelha, distância entre costelas, distância dorso ventre, distância ventre solo, largura da cabeça, largura da garupa, largura entre ísquios, largura da orelha, perímetro da canela, perímetro da rabada, perímetro torácico. Os resultados evidenciaram que os animais apresentaram peso médio de $334 \pm 39 \mathrm{~kg}$ e idade aproximada a primeira gestação de $29 \pm 3$ meses. As medidas morfométricas de altura da cernelha, altura do posterior, comprimento do corpo, comprimento da garupa, largura da cabeça, largura da garupa, largura entre ísquios, perímetro da rabada e perímetro torácico foram significativamente superiores nos animais gestantes. Pode-se concluir com estes resultados que há relação entre mensurações morfométricas e 0 estabelecimento da primeira 
gestação em novilhas Nelore.

Palavras-chave: bovinos, medidas morfométricas, precocidade sexual INTRODUCTION

Weight evaluation of performance of animals is closely related to measurements of weight, however, other measures relative to the development and structure of the body of beef cattle should also be considered. Linear or morphometric measurements, such as height and length are more accurate size parameters to determine maturity than weight, since the latter may undergo periodic fluctuations, depending on the nutritional status of the animals, whereas linear body measurements are constant (Pacheco et al., 2008).

Linear measurements are parameters of physical development of animals that are, at the same time, also related to their reproductive development (Joubert, 1954). Within this context, special mention should be made of the relationship between thoracic perimeter and the weight:height ratio with body condition (Thompson et al., 1983) and the high correlation between height, weight and age with the onset of puberty (Vargas et al., 1998). These characteristics can be measured quantitatively, and are considered to be effective tools to assess growth and body development, since they are directly related to the biological functions of the animals (Costa Júnior et al., 2006).

In addition, morphometric measures provide supplementary information used to determine genetic and phenotypic trends in the development of the animals over the years, and which may be effective to visualize and monitor the body characteristics directly associated with the reproduction and re-breeding of the animals (Gusmão Filho et al., 2009).

Considering the importance of identifying precocious animals to maximize the production cycle, the objective of this study was to characterize and establish correlations between age, weight, body condition and morphometric measurements with the onset of the reproductive life of Nellore heifers of the Mocha (polled).

\section{MATERIAL AND METHODS}

A total of 56 heifers of the Mocha (polled) variety of the Nellore breed, born between August and December 2006, weaned at an average age of 7.5 months of age and weighing between 170 and $230 \mathrm{~kg}$ were evaluated. The heifers were placed on the experiment at an average age of 16 months and reared on cultivated (Brachiaria decumbens) pasture (Embrapa Cerrados - Planaltina-DF), with a stocking rate of $1 \mathrm{AU} / \mathrm{ha}$. The females were supplemented with mineral salt placed in covered feeding troughs during the rainy season and with protein salt in the dry season to maintain appropriate body condition throughout the year. The experimental animals were dewormed and vaccinated in accordance with the prophylactic vaccination schedule for the region.

The heifers were evaluated from 16 to 32 months of age, at intervals of two months, and assessed for the following parameters: weight, body condition, body morphometrics (16 measurements) and pregnancy diagnosis.

Two bulls (one bull per 28 heifers) were introduced into the herd to determine the beginning of the reproductive life of the females, starting from the second evaluation session, i.e. when they were about 18 months of age. Pregnancy diagnosis was performed by transrectal ultrasonography, using a 7.5 Mhz linear rectal probe from the third 
assessment onwards (60 days after introducing the bulls). The age interval to first pregnancy was determined considering the age of the animal at the evaluation session when pregnancy was diagnosed and the age of the animal at the preceding session.

Body condition was determined by the method proposed by Kilkenny (1978), by assigning a rating on a scale from 1 to 5 , where, 1 = very thin, $2=$ thin, $3=$ regular, $4=$ fat and $5=$ very fat.

The morphometric measurements were taken using a tape measure, with a precision of one millimeter: withers height $(\mathrm{WH})$, measured as the distance from the top of the shoulder blades to the elbow and from the elbow to the ground; rump height $(\mathrm{RH})$, the vertical distance from the dorsal aspect of the animal's tail base to the beam; body length $(\mathrm{BL})$, the distance between the humerus-scapula articulation (shoulder) and the extremity of the ischiatic tuberosity; head length (HL), the distance between the tip of the nose and the posterior end of the subopercle; rump length $(R L)$, the distance between cranial part of the iliac tuberosity to the caudal aspect of the ischiatic tuberosity; ear length (EL), the distance between the base of the ear and the tip; distance between ribs (DR), the medial region of the space between the 12th and 13th ribs; distance from dorsal spine to belly (DDB), the distance between the top of the shoulder blades to the sternum or breastbone; the distance from ground to belly (DGB), the distance between region of the sternum or breastbone up to the extremity of the anterior member; head width $(\mathrm{HW})$, the distance between the outer margins of each orbit; rump width (RW), the distance between the most posterior point of the pinbones; width between ischiums (WI), the distance between the points of the ischium bone; ear width (EW), the distance between the outer margins of the medial region of the ear; cannon bone perimeter $(\mathrm{CP})$, the circumference measured just below the knee (in the medial portion of the metacarpal bone), tail implantation perimeter (TIP) the perimeter measured at the base of the tail, thoracic perimeter (TP), measurement based on the sternum or breastbone and the top of the shoulder blades.

The data obtained were analyzed by the SAS software program (Statistical Analysis System, version 9.2, 2008 update) and using the GLM (analysis of variance) and CORR (correlation) procedures.

\section{RESULTS AND DISCUSSION}

Thirty-seven heifers (66\%) became pregnant during the experiment and, at the beginning of their reproductive life, had an average weight of $333 \pm 39 \mathrm{~kg}$, heavier than found by Restle et al. (1999) and Oliveira et al. (2009) who reported weights at first pregnancy of $299 \pm 20 \mathrm{~kg}$ and $292 \pm 3.8 \mathrm{~kg}$, respectively. The weight difference between the animals in this experiment and the weight values described by the abovementioned authors is probably due to the different handling techniques used on each farm, with the animals assessed by Oliveira et al. (2009) pertaining to a herd that participated in a breed improvement program, which would account for the lower weight values reported in their study.

When becoming pregnant for the first time, the weight of the heifers represented about $73 \%$ of the adult weight, considering the average weight of $456 \mathrm{~kg}$ of the females of the same herd. This value is, at the same time, greater than that reported by Montanholi et al. (2004), who found a percentage of $65 \%$ of the adult weight $(460 \mathrm{~kg})$, but lower than the value reported by Freneau et al. (2008) who found that heifers of the herd they evaluated weighed on average $85 \%$ of the mean 
adult weight $(450 \mathrm{~kg})$ when they became pregnant for the first time. These variations may be explained by differences in nutrition and genetic variations between the herds. Animals raised on farms using nutritional strategies or treatments to promote faster weight gain tend to begin their reproductive life at an earlier age, since animals with greater initial development tend to reach their sexual maturity at a young age and at a proportionally lighter weight compared to the adult weight.

The approximate age of first pregnancy of the heifers in this experiment was between 26 and 33 months, values that are close to those reported by Restle et al. (1999), who reported an age interval between 24 and 28 months; however, with a pregnancy rate of $53 \%$, lower than the rate of $66 \%$ found in this study. Silva et al. (2005) observed a pregnancy rate of $42 \%$ when the experimental animals were 24 months of age. Oliveira et al. (2009), working with 19-to-24-month-old heifers obtained a pregnancy rate of $25 \%$ when the females were not stimulated by the presence of bulls during re-breeding and a pregnancy rate of $66 \%$ for the females stimulated by bulls. According to Vaz \& Lobato et al. (2010) and Gojjam et al. (2011) another reason for the variations in the rate of pregnancy may be attributed to the effect(s) of the weight or weight gain of the animals.

Another factor related to changes in the pregnancy rates may be associated with increased body condition scores (Santos et al., 2009). This situation was observed in this study, in which most of the pregnant heifers had body condition scores $(P>0.05 \%)$ greater than those of nonpregnant animals (Figure 1). As a rule, the animals exhibiting the best body condition also have a better nutritional status, present better muscle development and greater fat deposition values, thereby promoting higher pregnancy rates. The use of the body condition score was found to be useful in the selection of animals most suited and in the best conditions to begin their reproductive cycle.

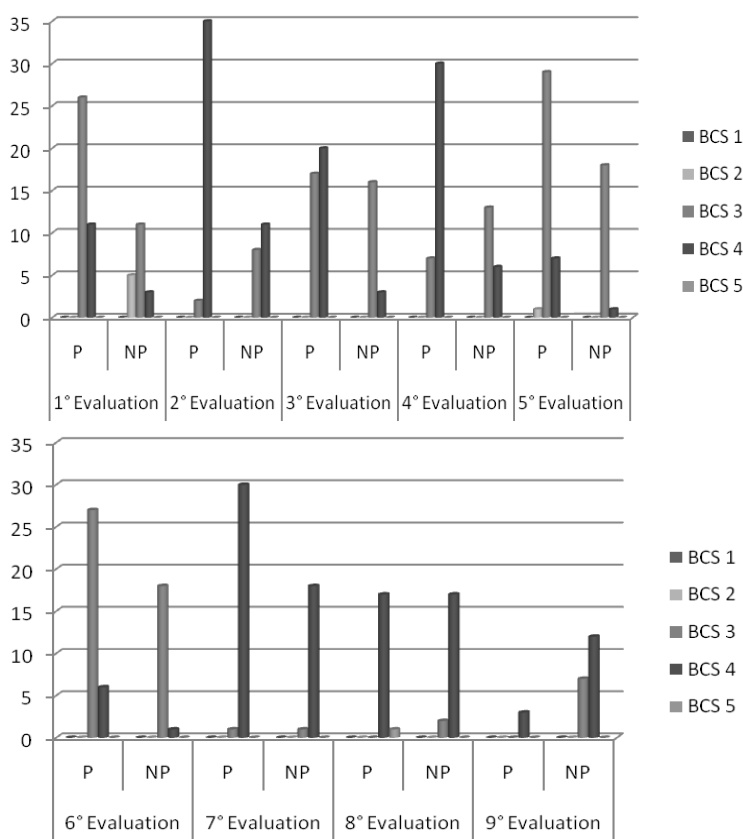

Figure 1 - Description of the number of heifers distributed across the different body condition scores (BCS) and the groups (Pregnant - $\mathrm{P}$ and non-pregnant - NP) during each information evaluation session performed during the experiment.

The age interval in which the first pregnancy occurs (26 to 33 months) is close to the average age interval for first pregnancy reported for Zebu cattle breeds. According to Nogueira (2004), the Brazilian average age of first conception in beef cattle is 31 months, and may vary from 16 to 40 months.

The high age of the heifers at the beginning of their reproductive activity observed in this study may be the result of a prolonged dry season during rebreeding. In this period (the year of 2007) the yearly rainfall was considerably lower (varying from 269 to 901 mm - Embrapa Cerrados - CPAC; www.agritempo.gov.br/agroclima/sumari o) than the average rainfall figures of the previous years, leading to a lack of feed, which consequently affected the 
productive and characteristics of

reproductive investigated. According to Shiotsuki et al. (2009), weight gain and growth during the post-weaning period are important in determining the age at which the reproductive cycle begins. Furthermore, Boligon et al. (2011) cite feeding treatments and selection processes as additional factors influencing the determination of this age.

Table 1 - Mean and standard deviation of morphometric characteristics of Nellore breed heifers pregnant and not pregnant, raised at Embrapa Cerrados in Planaltina - DF.

\begin{tabular}{|c|c|c|c|c|}
\hline \multirow[t]{2}{*}{$\begin{array}{l}\text { Measurements } \\
(\mathrm{cm})\end{array}$} & \multicolumn{2}{|r|}{ Pregnant } & \multicolumn{2}{|r|}{ Not pregnant } \\
\hline & Mean & Standard deviation & Mean & Standard deviation \\
\hline Withers height & $126,50^{\mathrm{a}}$ & 4,48 & $120,66^{b}$ & 5,20 \\
\hline Rump height & $133,42^{\mathrm{a}}$ & 3,84 & $128,32^{b}$ & 6,68 \\
\hline Body length & $127,71^{\mathrm{a}}$ & 5,34 & $121,39^{\mathrm{b}}$ & 7,70 \\
\hline Head length & $43,51^{\mathrm{a}}$ & 1,85 & $40,92^{\mathrm{a}}$ & 2,29 \\
\hline Rump length & $41,66^{\mathrm{a}}$ & 1,52 & $39,19^{b}$ & 3,40 \\
\hline Ear length & $22,84^{\mathrm{a}}$ & 1,19 & $21,74^{\mathrm{a}}$ & 1,89 \\
\hline $\begin{array}{l}\text { Distance between } \\
\text { ribs }\end{array}$ & $2,36^{\mathrm{a}}$ & 0,71 & $2,32^{\mathrm{a}}$ & 0,75 \\
\hline $\begin{array}{l}\text { Distance from } \\
\text { dorsal spine to } \\
\text { belly }\end{array}$ & $58,31^{\mathrm{a}}$ & 2,99 & $55,47^{\mathrm{a}}$ & 3,73 \\
\hline $\begin{array}{l}\text { Distance from } \\
\text { ground to belly }\end{array}$ & $69,06^{\mathrm{a}}$ & 4,22 & $67,34^{\mathrm{a}}$ & 3,37 \\
\hline Head width & $17,15^{\mathrm{a}}$ & 1,11 & $16,42^{b}$ & 1,22 \\
\hline Rump width & $36,04^{\mathrm{a}}$ & 1,98 & $33,50^{\mathrm{b}}$ & 3,25 \\
\hline $\begin{array}{l}\text { Width between } \\
\text { ischiums }\end{array}$ & $18,42^{\mathrm{a}}$ & 2,18 & $16,71^{b}$ & 2,22 \\
\hline Ear width & $10,08^{\mathrm{a}}$ & 0,90 & $9,84^{\mathrm{a}}$ & 1,01 \\
\hline $\begin{array}{l}\text { Cannonbone } \\
\text { perimeter }\end{array}$ & $16,97^{\mathrm{a}}$ & 0,74 & $16,32^{\mathrm{a}}$ & 1,25 \\
\hline $\begin{array}{l}\text { Tail implantation } \\
\text { perimeter }\end{array}$ & $19,01^{\mathrm{a}}$ & 1,22 & $17,32^{\mathrm{b}}$ & 1,38 \\
\hline $\begin{array}{l}\text { Thoracic } \\
\text { perimeter }\end{array}$ & $152,04^{\mathrm{a}}$ & 5,64 & $141,66^{\mathrm{b}}$ & 7,70 \\
\hline
\end{tabular}

Different lowercase letters, in the same row, indicate significant difference $(P<0,05)$.

Table 1 shows the mean values of morphometric measurements of animals pregnant and not pregnant group. The characteristics Withers height, Rump height, Body length, Rump length, Rump width, Width between ischiums, Tail implantation perimeter and Thoracic perimeter were body traits that were found to show significant differences $(P<0.05)$. Body length, Rump width and Width between ischiums are traits associated with reproduction, since animals that exhibit larger measures of these traits have greater ease to giving birth due to their wider pelvic opening. According to Barreto et al. (2004), the greater dimensions of the pelvis reduce the probability of dystocic births. On the other hand, Withers height, Rump height, Body length and Thoracic perimeter traits are related to the development of the animal, i.e. larger measures at a younger age correspond to better initial development. According to Koury Filho et al. (2009) the selection for larger height measurements correspond keeping larger animals adult age.

The heifers that showed earlier development became pregnant before the other heifers on the experiment. These results corroborate the findings of Baidi et al. (2008) and Pereira et al. (2010), who believed that animals showing precocious development also initiate the reproductive cycle earlier, thereby reducing the age at first calving and increasing the chances of conception at a younger age.

The Head width, Head length, Ear length and Ear width traits are associated with the development of the animals and breed characterization and are measurements that demonstrate the growth of the animal. These traits are also typically less influenced by the environment and can be used in the standardizing of breed types; however, they are of little importance to animal production. Costa Júnior et al. (2006), working with sheep of the Santa Inês breed observed that the morphometric characteristics are the variables that are less influenced by the environment when compared to weight. Similar observations were made by Pacheco et al. (2008) and Montanholi et al. (2008) who, studying cattle, reported that measurements of height are less susceptible to environmental variations and to the availability of feed resources than life weight. These authors further observed that the upper and lower limits of morphometric measures are reached at an earlier stage of life than the adult weight, since the latter may undergo a series of variations throughout the 
lifespan of the animal. For that reason, measuring the height is an alternative to determine the point in time when the reproductive life of heifers begins.

Table 2 depicts all the correlations between the characteristics investigated. The Withers height, Rump height, Body length, Head length, Rump length, Distance from dorsal spine to belly, Rump width, Cannon bone perimeter, Tail implantation perimeter, Thoracic perimeter traits show high correlations $(>0.60)$ with age and weight. Positive correlations were also found by Costa Júnior et al. (2006) and Pinheiro \& Jorge (2010) between morphometric measures and body weight.

Table 2 - Correlations between morphometric measures, weight and age of 56 heifers of the Nellore breed, raised at Embrapa Cerrados in Planaltina - DF.

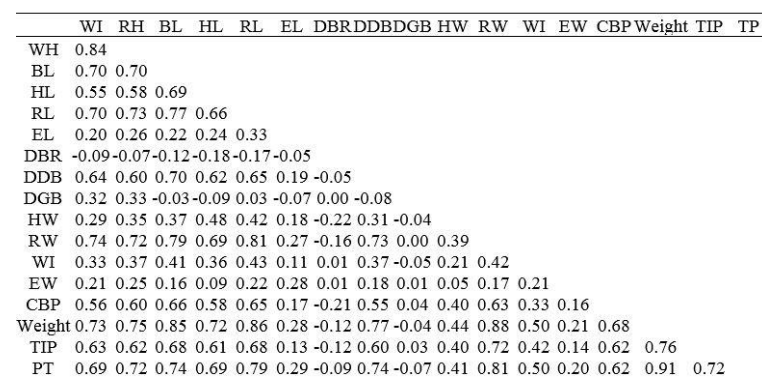

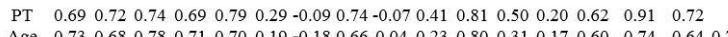
WH - Withers height, $\mathrm{RH}-\mathrm{Rump}$ height, $\mathrm{BL}-$ Body length, HL - Head length, RL - Rump length, $E L$ - Ear length, DBR - Distance between ribs, DDB - Distance from dorsal spine to belly, DGB - Distance from ground to belly, BS - Body score, HW - Head width, RW Rump width, WI - Width between ischiums, EW - Ear width , CBP - Cannon bone perimeter, Weight, TIP - Tail implantation perimeter, TP Thoracic perimeter, Age (Months).

In this study, high correlations were observed between weight, height and thoracic perimeter, since all the animals investigated were in the growing stage (Table 1). These parameters are of utmost importance for the characterization of the development of the animals. However, these correlations become less important with the development of the animals due to stabilization of the growth process (Montanholi et al., 2008).

The Ear length, Distance from ground to belly, Body Score, Head width, Width between ischiums, Ear width present low correlations $(<0.30)$ with age, that is, they are little influenced by the increase in age. The Distance between ribs trait showed negative correlation.

Table 3 shows the regression equations for the determination of the growth rate of all the characteristics investigated. The growth rates of the Withers height, Rump height, Body length, Head length, Rump length, Distance from dorsal spine to belly, Rump width, Width between ischiums Weight, Cannon bone perimeter, Tail implantation perimeter and Thoracic perimeter characteristics of the pregnant animals are lower than those of the nonpregnant animals, in spite of the fact that the actual measures of the pregnant animals are larger. These differences in the growth rates and measures may be explained by a greater or more intense initial development of the pregnant heifers.

Table 3 - Regression equations to determine the growth rate of the morphometric characteristics of pregnant and non-pregnant heifers of the Nellore breed.

\begin{tabular}{ccc}
\hline Measures & Pregnant & Non-pregnant \\
\hline Withers height & $112.53+0.71^{*} \mathrm{Age}^{\mathrm{a}}$ & $104.22+1.02^{*} \mathrm{Age}^{\mathrm{b}}$ \\
Rump height & $121.44+0.65^{*} \mathrm{Age}^{\mathrm{a}}$ & $112.85+0.93^{*} \mathrm{Age}^{\mathrm{b}}$ \\
Body length & $109.23+1.23^{*} \mathrm{Age}^{\mathrm{a}}$ & $93.77+1.83^{*} \mathrm{Age}^{\mathrm{b}}$ \\
Head length & $37.08+0.40^{*} \mathrm{Age}^{\mathrm{a}}$ & $32.80+0.56^{*} \mathrm{Age}^{\mathrm{a}}$ \\
Rump length & $36.30+0.34^{*} \mathrm{Age}^{\mathrm{a}}$ & $29.00+0.62^{*} \mathrm{Age}^{\mathrm{b}}$ \\
Ear length & $22.31+0.03^{*} \mathrm{Age}^{\mathrm{a}}$ & $20.11+0.12^{*} \mathrm{Age}^{\mathrm{a}}$ \\
Distance between ribs & $2.95-0.03^{*} \mathrm{Age}^{\mathrm{a}}$ & $2.94-0.03^{*} \mathrm{Age}^{\mathrm{a}}$ \\
Distance from dorsal spine to belly & $50.52+0.52^{*} \mathrm{Age}^{\mathrm{a}}$ & $45.81+0.70^{*} \mathrm{Age}^{\mathrm{a}}$ \\
Distance from ground to belly & $67.49+0.03^{*} \mathrm{Age}^{\mathrm{a}}$ & $67.55+0.01^{*} \mathrm{Age}^{\mathrm{a}}$ \\
Head width & $16.97+0.02^{*} \mathrm{Age}^{\mathrm{a}}$ & $14.30+0.11^{*} \mathrm{Age}^{\mathrm{b}}$ \\
Rump width & $25.24+0.63^{*} \mathrm{Age}^{\mathrm{a}}$ & $18.17+0.95^{*} \mathrm{Age}^{\mathrm{b}}$ \\
Width between ischiums & $18.50+0.04^{*} \mathrm{Age}^{\mathrm{a}}$ & $13.84+0.20^{*} \mathrm{Age}^{\mathrm{b}}$ \\
Ear width & $9.376+0.04^{*} \mathrm{Age}^{\mathrm{a}}$ & $9.34+0.039^{*} \mathrm{Age}^{\mathrm{a}}$ \\
Cannonbone perimeter & $15.51+0.11^{*} \mathrm{Age}^{\mathrm{a}}$ & $13.73+0.18^{*} \mathrm{Age}^{\mathrm{a}}$ \\
Tail implantation perimeter & $16.63+0.14^{*} \mathrm{Age}^{\mathrm{a}}$ & $12.98+0.29^{*} \mathrm{Age}^{\mathrm{b}}$ \\
Thoracic perimeter & $137.72+1.00^{*} \mathrm{Age}^{\mathrm{a}}$ & $113.56+1.84^{*} \mathrm{Age}^{\mathrm{b}}$ \\
\hline
\end{tabular}

a,bDifferent lowercase letters, in the same row, indicate significant difference $(P<0,05)$.

Traits such as Ear length, Head length and Ear width exhibit low growth rates and little variation between the animals throughout the experiment, since these are characteristics closely 
linked to the characterization of the Nellore breed.

Distance between ribs shows negative regression values. This can be justified by the position of the animal tied in the containment pen when the measurements were taken. In addition, the increase in body mass of the animals makes it more difficult to get access to the space between the ribs. This fact was also observed by Cyrillo et al. (2000), who encountered difficulties during the taking of measurements because of the restless behaviour of the animals.

\section{CONCLUSION}

The measurements of weight, body condition score and morphometric measures showed positive correlations among each other and provide very useful tools for the selection of precociously developing animals, with the additional advantage of being characteristics that are easy to be obtained and applied by farmers.

Studies on animal handling, feeding and reproduction should be conducted with the objective of enhancing the effectiveness and impact of the measured parameters, so as to develop animals of the Nelore breed raised in the open that begin their reproductive life earlier.

\section{REFERENCES}

BALDI, F.; ALENCAR, M. M.; FREITAS, A. R.; et al. Parâmetros genéticos para características de tamanho e condição corporal, eficiência reprodutiva e longevidade em fêmeas da raça Canchim. Revista Brasileira de Zootecnia, v. 37, n. 2, p. 247-253, 2008.

BARRETO, M. B. P.; SANTOS, R. M. B.; WISCHRAL, A.; et al. Pelvimetria e pelvilogia em fêmeas bovinas da raça Girolanda em diferentes estágios reprodutivos. Ciência Veterinária nos Trópicos, v. 7, n. 2 e 3, p. 131-139, 2004.

BOLIGON, A. A.; ALBUQUERQUE, L. $G$. Genetic parameters and relationships of heifer pregnancy and age at first calving with weight gain, yearling and mature weight in Nelore cattle. Livestock Science, n.141, p.12-16, 2011.

COSTA JÚNIOR, G. S.; CAMPELO, J. E. G.; AZEVÊDO, D. M. M. R.; et al. Caracterização morfométrica de ovinos da raça Santa Inês criados nas microrregiões de Teresina e Campo Maior, Piauí. Revista Brasileira de Zootecnia, v. 35, n. 6, p. 2260-2267, 2006.

CYRILLO, J. N. S. G.; RAZOOK, A. G.; FIGUEIREDO, L. A.; et al. Efeito da seleção para peso pós-desmame sobre medidas corporais e perímetro escrotal de machos Nelore de Sertãozinho (SP). Revista Brasileira de Zootecnia, v. 29, n. 2, p. 403-412, 2000.

FRENEAU, G. E.; SILVA, J. C. C.; BORJAS, A. L. R.; et al. Estudo de medidas corporais, peso vivo e condição corporal de fêmeas de raças Nelore Bos taurus indicus ao longo de doze meses. Ciência Animal Brasileira, v. 9, n. 1, p. 76-85, 2008.

GOJJAM, Y.; TOLERA, A.; MESFIN, R. Management options to accelerate growth rate and reduce age at first calving in Friesian-Boran crossbred heifers. Tropical Animal Health and Production, v.43, p.393-399, 2011.

GUSMÃO FILHO, J. D.; TEODORO, S. M.; CHAVES, M. A.; et al. Análise fatorial de medidas morfométricas em ovinos tipo Santa Inês. Archivos de Zootecnia, v.58, p.289-292, 2009. 
JOUBERT, D. M. The influence of winter nutritional depressions on the growth, reproduction and production of cattle. Journal of Agricultural Science, Cambridge, v. 44, p. 5-65, 1954.

KILKENNY, J. B. Reproductive performance of beef cows. World Review Animal Production, v. 4, n. 3, p. 66-74, 1978.

KOURY FILHO, W.; ALBUQUERQUE, L. G.; ALENCAR, M. M.; et al. Estimativas de herdabilidade e correlações para escores visuais, peso e altura ao sobreano em rebanhos da raça Nelore. Revista Brasileira de Zootecnia, v.38, n.12, p.2362-2367, 2009.

MONTANHOLI, Y. R.; BARCELLOS, J. O. J.; BORGES, J. B.; et al. Ganho de peso na recria e desempenho reprodutivo de novilhas acasaladas com sobreano. Pesquisa Agropecuária Brasileira, v.39, n.12, p.1253-1259, 2004.

MONTANHOLI, Y. R.; BARCELLOS, J. O. J.; COSTA, E. C. Variação nas medidas corporais e desenvolvimento do trato reprodutivo de novilhas de corte recriadas para 0 acasalamento aos 18 meses de idade. Ciência Rural, v.38, n.1, p.185-190, 2008.

NOGUEIRA, G. P. Puberty in South American Bos indicus zebu cattle. Animal Reproduction Science, v.8283, p.361-372, 2004.

OLIVEIRA, C. M. G.; OLIVEIRA FILHO, B. D.; GAMBARINI, M. L.; et al. Effects of biostimulation and nutritional supplementation on pubertal age and pregnancy rates of Nelore heifers (Bos indicus) in a tropical environment. Animal Reproduction Science, v.113, p.38-43, 2009.
PACHECO, A.; QUIRINO, C. R.; PINHEIRO, O. L. V. M.; et al. Medidas morfométricas de touros jovens e adultos da raça Guzerá. Revista Brasileira de Saúde e Produção Animal, v.9, n.3, p.426-435, 2008.

PEREIRA, M. C.; YOKOO, M. J.; BIGNARDI, A. B.; et al. Altura da garupa e sua associação com características reprodutivas e de crescimento na raça Nelore. Pesquisa Agropecuária Brasileira, v.45, n.6, p.613-620, 2010.

PINHEIRO, R. S. B.; JORGE, A. M. Medidas biométricas obtidas in vivo e na carcaça de ovelhas de descarte em diferentes estágios fisiológicos. Revista Brasileira de Zootecnia, v.39, n.2, p.440-445, 2010.

RESTLE, J.; POLLI, V. A.; SENNA, D. $B$. Efeito de grupo genético e heterose sobre a idade e peso à puberdade e sobre o desempenho reprodutivo de novilhas de corte. Pesquisa Agropecuária Brasileira, v.34, n.4, p.701-707, 1999.

SANTOS, S. A.; ABREU, U. G. P.; SOUZA, G. S.; et al. Condição corporal, variação de peso e desempenho reprodutivo de vacas de cria em pastagem nativa no Pantanal. Revista Brasileira de Zootecnia, v.38, n.2, p.354-360, 2009.

SAS - STATISTICAL ANALYSES SYSTEM. 1999. User's guide: Statistics. Version 9.2 (TS MO) Cary: 2008.

SHIOTSUKI, L.; SILVA, J. A. II de V.; ALBUQUERQUE, L. G. Associação genética de prenhez aos 16 meses com o peso à desmama e o ganho de peso em animais da raça Nelore. Revista Brasileira de Zootecnia, v.38, n. 7, p. 1211-1217, 2009. 
SILVA, J. A. de V.; DIAS, L. T.; ALBUQUERQUE, L. G.; GOODRICH, R. D.; RUST, J. R.; et al. Estudo genetic da precocidade sexual de novilhas em um rebanho Nelore. Revista Brasileira de Zootecnia, v.34, n.5, p.1568-1572, 2005.

THOMPSON, W. R.; THEUNINCK, D. H.; MEISKE, J. C.; et al. Linear measurements and visual appraisal as estimators of percentage empty body fat of beef cows. Journal of Animal Science, v.56, n.4, p.755-760, 1983.

VARGAS, C. A.; ELZO, M. A.; CHASE JR, C. C.; et al. Estimation of genetic parameters for scrotal circumference, age at puberty in heifers, and hip height in Brahman cattle. Journal of Animal Science, v.76, n.10, p.2536-2541, 1998.

VAZ, R. Z.; LOBATO, J. F. P. Efeito da idade de desmame no desempenho reprodutivo de novilhas de corte exposta à reprodução aos 13/15 meses de idade. Revista Brasileira de Zootecnia, v.39, n.1, p.142-150, 2010. 